\title{
Article \\ Zn-Al Layered Double Hydroxides Synthesized on Aluminum Foams for Fluoride Removal from Water
}

\author{
Yuliu Li ${ }^{1}\left(\mathbb{D}\right.$, Riccardo Narducci ${ }^{1,2}{ }^{\mathbb{D}}$, Alessandra Varone ${ }^{1}$, Saulius Kaciulis ${ }^{3} \mathbb{D}$, Eleonora Bolli ${ }^{3} \mathbb{D}$ \\ and Roberto Pizzoferrato $1, *$ (D) \\ 1 Department of Industrial Engineering, University of Rome Tor Vergata, Via del Politecnico 1, \\ 00133 Rome, Italy; yuliuli1022@gmail.com (Y.L.); riccardo.narducci@uniroma2.it (R.N.); \\ alessandra.varone@uniroma2.it (A.V.) \\ 2 International Laboratory "Ionomer Materials for Energy", University of Rome Tor Vergata, \\ Via del Politecnico 1, 00133 Rome, Italy \\ 3 Institute for the Study of Nanostructured Materials, ISMN-CNR, Monterotondo Stazione, 00015 Rome, Italy; \\ saulius.kaciulis@cnr.it (S.K.); eleonora.bolli@ismn.cnr.it (E.B.) \\ * Correspondence: pizzoferrato@uniroma2.it
}

check for updates

Citation: Li, Y.; Narducci, R.; Varone,

A.; Kaciulis, S.; Bolli, E.; Pizzoferrato,

R. Zn-Al Layered Double

Hydroxides Synthesized on

Aluminum Foams for Fluoride

Removal from Water. Processes 2021, 9 ,

2109. https://doi.org/10.3390/pr

9122109

Academic Editor:

Avelino Núñez-Delgado

Received: 20 October 2021

Accepted: 22 November 2021

Published: 24 November 2021

Publisher's Note: MDPI stays neutral with regard to jurisdictional claims in published maps and institutional affiliations.

Copyright: (c) 2021 by the authors. Licensee MDPI, Basel, Switzerland. This article is an open access article distributed under the terms and conditions of the Creative Commons Attribution (CC BY) license (https:// creativecommons.org/licenses/by/ $4.0 /)$.

\begin{abstract}
Fluoride excess in water represents an environmental issue and a risk for human health since it can cause several diseases, such as fluorosis, osteoporosis, and damage of the nervous system. Layered double hydroxides (LDHs) can be exploited to remove this contaminant from water by taking advantage of their high ion-exchange capability. LDHs are generally mixed with polluted water in the form of powders, which then cause the problem of uneasy separation of the contaminated LDH sludge from the purified liquid. In this work, Zn-Al LDH films were directly grown in situ on aluminum foams that acted both as the reactant and substrate. This method enabled the removal of fluoride ions by simple immersion, with ensuing withdrawal of the foam from the de-contaminated water. Different LDH synthesis methods and aluminum foam types were investigated to improve the adsorption process. The contact time, initial fluoride concentration, adsorbent dosage, and $\mathrm{pH}$ were studied as the parameters that affect the fluoride adsorption capacity and efficiency. The highest absorption efficiency of approximately $70 \%$ was obtained by using two separate growth methods after four hours, and it effectively reduced the fluoride concentration from $3 \mathrm{mg} / \mathrm{L}$ to $1.1 \mathrm{mg} / \mathrm{L}$, which is below the threshold value set by WHO for drinking water.
\end{abstract}

Keywords: LDH; fluoride adsorption; water remediation; XPS; coprecipitation; urea hydrolysis

\section{Introduction}

Fluoride is the monoatomic anion of fluorine with a relatively small radius. It is considered one of the essential micronutrients for the human body, as it can prevent dental caries and increase bone strength [1-4]. However, with the increasing popularity of fluoridated drinking water, problems have gradually emerged. More and more evidence shows that fluoride excess in water can represent a serious health hazard. Long-term excessive intake of fluoride may cause various diseases, including dental fluorosis, skeletal fluorosis, thyroid disorder, Alzheimer's syndrome, etc. The maximum amount of fluoride allowed in drinking water is $1.5 \mathrm{mg} / \mathrm{L}$ (1.5 ppm) according to the World Health Organization (WHO), but different standards apply in different countries and are regulated by various organizations [5]. High concentrations of fluoride can be found in groundwater and surface water, due to geochemical reactions and human activities. Wastewaters from semiconductor, solar cell, and metal-plating industries also contain very high concentrations of fluoride, in the range from $100 \mathrm{ppm}$ to $10,000 \mathrm{ppm}$, which is due to the use of hydrofluoric acid (HF) for cleaning and etching processes [6,7]. It is estimated that there are over 200 million people among 25 countries in the world consuming drinking water that exceeds fluoride standards $[8,9]$. Therefore, removal of the excess amount of fluoride in drinking water is in high 
demand, and different strategies, such as ion exchange, precipitation, adsorption, membrane separation, reverse osmosis, and electrocoagulation have been adopted [5,10-12]. Among these methods, adsorption is one of the most used, due to its cost-effectiveness, easy operation, simple physical process, stable performance and, most importantly, the multiple choice of sorbents [13].

Since Hochstetter in Sweden discovered the existence of natural ore-hydrotalcite in 1842 [14,15], the development of layered materials has made a history of more than 150 years. Layered double hydroxides (LDHs) are a class of ionic solids characterized by a layered structure, such as brucite with the general formula $\left[\mathrm{M}_{1-\mathrm{x}}{ }^{2+} \mathrm{M}_{\mathrm{x}}{ }^{3+}(\mathrm{OH})_{2}\right]^{\mathrm{x}+}\left[\mathrm{A}_{\mathrm{x} / \mathrm{n}}{ }^{\mathrm{n}-}\right.$ $\cdot \mathrm{mH}_{2} \mathrm{O}^{\mathrm{x}-}$, where $\mathrm{x}$ is usually between 0.20 and 0.33 . Common divalent metal cations $\left(\mathrm{M}^{2+}\right)$ that make up LDHs are $\mathrm{Mg}^{2+}, \mathrm{Zn}^{2+}, \mathrm{Ni}^{2+}$ and $\mathrm{Cu}^{2+}$; on the other hand, the trivalent metal cations $\left(\mathrm{M}^{3+}\right)$ range over $\mathrm{Al}^{3+}, \mathrm{Fe}^{3+}$, and $\mathrm{Cr}^{3+}$. The substitution of divalent metal ions by trivalent metal cations makes the hydroxide sheets positively charged and require the intercalation of $\mathrm{n}^{-}$valent anions between the layers to maintain the electrical neutrality of the structure. The common inorganic interlayer anions include $\mathrm{Cl}^{-}, \mathrm{Br}^{-}, \mathrm{NO}_{3}{ }^{-}, \mathrm{OH}^{-}$, $\mathrm{CO}_{3}{ }^{2-}, \mathrm{SO}_{4}{ }^{2-}, \mathrm{PO}_{4}{ }^{3-}$, etc. $[15,16]$. The layered structure and the possibility of swapping intercalated anions make LDH an excellent anion exchange material with the capability of adsorbing anions from the liquid environment. The anion exchange capacity of LDHs depends on the ratio of the component metal cations, the anion capacity to stabilize the lamellar structure, and the molecular mass of the cations and anions involved. According to Miyata [17], the ion-exchange equilibrium constants of monovalent anions for LDHs are in the sequence $\mathrm{OH}^{-}>\mathrm{F}^{-}>\mathrm{Cl}^{-}>\mathrm{Br}^{-}>\mathrm{NO}_{3}{ }^{-}>\mathrm{I}^{-}$, while for divalent anions, they are in the sequence $\mathrm{CO}_{3}{ }^{2-}>\mathrm{SO}_{4}{ }^{2-}$. The smaller the radius of the adsorbed anions, the larger the interlayer spacing of the restored layered structure, and the higher the anion valence, the easier it is to enter the interlayer [18].

With adsorption catalytic properties, high thermal stability, and acid and alkali resistance, LDHs have shown a very wide range of application prospects, for instance, in the preparation of catalysts [19-21] and composite materials [22-24], biomedicine [25-27], environmental governance [28], and also as a new type of water treatment agent [29,30]. In addition, due to their ion-exchange properties mentioned above, LDHs have been employed in the adsorption of varieties of ions in water, for example, heavy metals (such as arsenic [31,32], lead [33], mercury [34], selenium [35] and copper [36,37]) organic dyes [38-41], and various anions (phosphate, fluoride, carboxylate, and sulfate) [42,43].

For the removal of contaminants, LDHs are commonly used in the form of powder, as microparticles or nanoparticles, either added to the contaminated water or synthesized in situ by the co-precipitation method. However, the difficulties of the ensuing necessary solid-liquid separation reduce cost-effectiveness, may affect the water quality after treatment, and also result in unsatisfying recycling performance [44]. To simplify the separation process and increase the recycling capability, $\mathrm{Zn}-\mathrm{Al} \mathrm{LDH}$ were grown on the surface of aluminum foams, where the metal foam acted as the reactant as well as the substrate for the LDH synthesis and subsequent use [36,45,46]. Previously reported investigations $[36,47]$ involved low amounts and thin layers of $\mathrm{LDH}$ on aluminum foam for the removal of copper ions from water. In this study, to improve the quantity and thickness of deposited films, we adopted different synthesis methods, including a separate second growth on the first layer by coprecipitation and a continuous second growth by adding aluminum salt with urea hydrolysis. With this approach, the fluoride concentration in water was effectively reduced below the guideline value set by WHO for drinking water. The LDH morphology and structure were characterized by scanning electron microscopy (SEM), X-ray diffraction (XRD), and X-ray photoelectron spectroscopy (XPS). The influence of contact time, adsorbent dosage, $\mathrm{pH}$, initial fluoride concentration, aluminum foam types, and different synthesis processes on the adsorption performance of LDH was investigated. The present LDH adsorbents aimed at providing a convenient strategy for industrial applications. 


\section{Materials and Methods}

\subsection{Materials}

Two types of aluminum foams with different pore sizes (Type I: 1.5-2.5 mm, Type II: $1.0-1.5 \mathrm{~mm}$ ), macroscopic densities (Type I: $0.31 \mathrm{~g} / \mathrm{cm}^{3}$, Type II: $0.23 \mathrm{~g} / \mathrm{cm}^{3}$ ) and macroscopic porosities (Type I: 88\%, Type II: 91\%) were used, as shown in Figure 1. The foams were cut with similar dimensions of $2.0 \times 1.5 \times 1.0 \mathrm{~cm}^{3}$, approximately. Zinc nitrate $\left(\mathrm{Zn}\left(\mathrm{NO}_{3}\right)_{2} \cdot 6 \mathrm{H}_{2} \mathrm{O}\right.$, reagent grade, $\left.98 \%\right)$, aluminum nitrate $\left(\mathrm{Al}\left(\mathrm{NO}_{3}\right)_{3} \cdot 9 \mathrm{H}_{2} \mathrm{O}\right.$, analysis grade), urea $(99 \%)$, sodium hydroxide $\left(\mathrm{NaOH}\right.$, anhydrous pellets), sodium nitrate $\left(\mathrm{NaNO}_{3}, \geq 99 \%\right)$, sodium fluoride (NaF, $\geq 99 \%$ ) and zirconium-SPADNS reagent were purchased from Merck KGaA (Darmstadt, Germany) and used as received. Fluoride solutions for adsorption experiment were prepared from $\mathrm{NaF}$ salt with deionized water purified by using a Milli-Q system (Millipore, Milford, MA, USA).

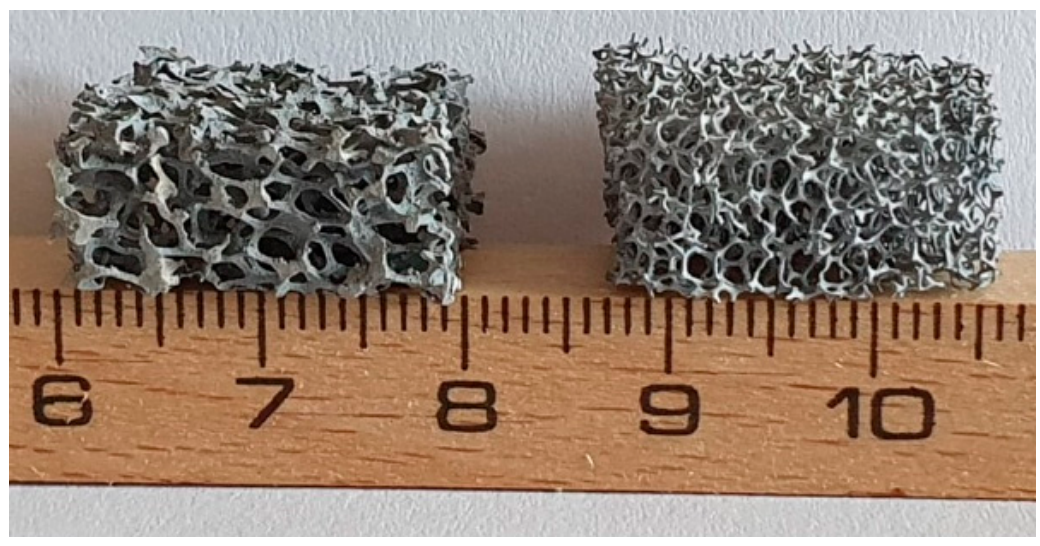

Figure 1. Structure of the two types of aluminum foam used in the present study: Type I (left), Type II (right).

\subsection{Synthesis of $\mathrm{Zn}-\mathrm{Al} \mathrm{LDH}$ on Aluminum Foams}

Decarbonized water was prepared by boiling distilled water at boiling temperature with a reflux condenser for $3 \mathrm{~h}$ to get rid of carbonate ions [48,49]. The aluminum foams were cleaned with commercial liquid dish soap, followed by a $0.1 \mathrm{M} \mathrm{NaOH}$ solution, ethanol with $10 \mathrm{~min}$ sonication, and finally with distilled water. Then, they were dried at $120{ }^{\circ} \mathrm{C}$ for one hour before use. Three different methods of LDH film growth were investigated: single growth (SG), separate two growths (STG) and continuous two growths (CTG). Performing a second growth was aimed to increase the amount and thickness of synthesized $\mathrm{LDH}$ and required the addition of $\mathrm{Al}^{3+}$ ions to the solution, as the surface of the aluminum foam was already covered by LDH after SG.

\subsubsection{Single Growth (SG)}

$\mathrm{Zn}\left(\mathrm{NO}_{3}\right)_{2} \cdot 6 \mathrm{H}_{2} \mathrm{O}(0.75 \mathrm{~g})$ and urea $(0.45 \mathrm{~g})$ were added to $0.5 \mathrm{~L}$ of decarbonized water to prepare a solution containing $5 \mathrm{mM} \mathrm{Zn}\left(\mathrm{NO}_{3}\right)_{2}$ and $15 \mathrm{mM}$ of urea. Urea acted as a $\mathrm{pH}$ regulator to stabilize the $\mathrm{pH}$ at around 7. Aluminum foams were held inside the zinc salt solution with nylon lines to maintain them in the middle of the solution, while a magnetic stirrer provided gentle mixing. The LDH film growth was carried out at $90{ }^{\circ} \mathrm{C}$ (silicone bath) for $12 \mathrm{~h}$ with nitrogen flux.

\subsubsection{Separate Two Growths (STG)}

After a SG process, the LDH-deposited Al foams were washed with ethanol and distilled water and dried at $120^{\circ} \mathrm{C}$ for one hour, followed by the weighting of mass. Then they were put into a new salt solution for coprecipitation growth. The new solution was made of $0.02 \mathrm{M} \mathrm{Zn}\left(\mathrm{NO}_{3}\right)_{2}(2.97 \mathrm{~g})$ and $0.01 \mathrm{M} \mathrm{Al}\left(\mathrm{NO}_{3}\right)_{3}(1.88 \mathrm{~g})$ with the ratio $\mathrm{Zn}: \mathrm{Al}=2: 1$ in $0.5 \mathrm{~L}$ of decarbonized water. The addition of $2 \mathrm{M} \mathrm{NaOH}$ was performed to adjust the $\mathrm{pH}$ 
to $8-10$. The second growth lasted for $18 \mathrm{~h}$ at $80^{\circ} \mathrm{C}$. Then, the foams were washed with ethanol and distilled water and dried at $120^{\circ} \mathrm{C}$ for one hour followed by weighing.

\subsubsection{Continuous Two Growth (CTG)}

After $12 \mathrm{~h}$ of the $\mathrm{SG}$ process, $\mathrm{Al}\left(\mathrm{NO}_{3}\right)_{3}$ salt $(0.47 \mathrm{~g})$ was added directly to the solution to obtain an aluminum concentration of $2.5 \times 10^{-3} \mathrm{M}(\mathrm{Zn}: \mathrm{Al}=2: 1)$ and to carry out a second growth by the urea method. The $\mathrm{pH}$ was adjusted to 7 by adding a $2 \mathrm{M} \mathrm{NaOH}$ solution, then the reaction was continued for $18 \mathrm{~h}$ at $80-90{ }^{\circ} \mathrm{C}$. After the reaction, the foams were washed with ethanol and distilled water, then dried at $120{ }^{\circ} \mathrm{C}$ for one hour with stirring at $200 \mathrm{rpm}$ for mixing. After the reaction, the foams were washed with ethanol and distilled water, then dried at $120^{\circ} \mathrm{C}$ for one hour followed by weighing.

\subsection{Characterization}

The crystal structure of the LDH grown on the aluminum foam surface was evaluated by XRD. XRD spectra were collected in the $2 \Theta$ angular range at $10-55^{\circ}$ by using $\mathrm{Cu}-\mathrm{K} \alpha$ radiation $\left(\lambda=1.5408 \AA\right.$ ) with $2 \Theta$ angular steps of $0.05^{\circ}$ and a counting time of 2 s per step. The phases were identified by using the JCPDS-ICDD database. The morphology of the deposited Zn-Al LDH was investigated through scanning electron microscopy observations (SEM Hitachi SU70, Hitachi, Tokyo, Japan). The XPS measurements were performed by using a spectrometer Escalab 250Xi (Thermo Fisher Scientific Ltd., East Grinstead, UK) equipped with a monochromatized $\mathrm{Al}-\mathrm{K} \alpha \mathrm{X}$-ray source and a six-channeltron detection system for spectroscopic analysis. The photoemission was collected at a constant pass energy of $100 \mathrm{eV}$ for the survey spectra and $50 \mathrm{eV}$ for the elemental regions. All the spectra were acquired in standard mode of the electromagnetic lens system corresponding to analysis area of approximately $1 \mathrm{~mm}$ in diameter. Spectroscopic data were processed by the Avantage v.5 software (Thermo Fisher Scientific Ltd., UK). UV-Vis spectroscopy was performed by using a Varian Cary 50 Scan spectrometer (Varian Inc., Palo Alto, CA, USA) in the range of 300-700 $\mathrm{nm}$.

\subsection{Fluoride Adsorption Experiments}

The aluminum foams with the $\mathrm{Zn}-\mathrm{Al} \mathrm{LDH}$ film grown on the surface were immersed in $20 \mathrm{~mL}$ of fluoride solution with an initial concentration of $3 \mathrm{mg} / \mathrm{L}$ or $10 \mathrm{mg} / \mathrm{L}$ in a $25 \mathrm{~mL}$ round-bottom flask. Nylon line was applied to maintain the foams in the central position of the solution. A small stirring bar was used to promote mixing by gentle stirring at $100 \mathrm{rpm}$. Adsorption was performed at room temperature and at the original $\mathrm{pH}$ of the fluoride solution (around 6). The nitrogen environment was provided to prevent the intercalation of carbonate groups.

Determination of the residual fluoride concentration was performed by using the SPADNS method [50-52] (SPADNS: sodium (2-para sulfophenylazo) 1,8-dihydroxy 3,6naphthalene disulfonate) and the UV-Vis spectrophotometer to measure the absorbance at $580 \mathrm{~nm}$. The detection was based on the reaction of fluoride and the red-colored complex, which produces a colorless complex anion $\left(\mathrm{ZrF}_{6}{ }^{2-}\right)$ and results in a decrease in optical absorbance. Calibration curves were recorded with a series of fluoride solutions. Dilution was applied for the high concentration values, which exceeded the linear limit of the calibration curve. Measurements of fluoride concentration were performed after 20, $40 \mathrm{~min}$ and $1,2,3,4$, and $24 \mathrm{~h}$ from the start of the experiment.

The $\mathrm{pH}$ of the $20 \mathrm{~mL}$ of the fluoride solution for adsorption was adjusted with a $0.01 \mathrm{M}$ $\mathrm{NaOH}$ or a $0.01 \mathrm{M} \mathrm{HNO}_{3}$ solution in the range of 5-10 to study the influence of $\mathrm{pH}$ with other conditions unchanged. The influence of contact time, initial fluoride concentration, $\mathrm{pH}$, and adsorbent dosage was based on the calculation of the adsorption capacity and adsorption efficiency.

The adsorbent dosage $(A D)$ was calculated by Equation (1):

$$
A D=\frac{m}{V}
$$


where $m$ is the mass of the adsorbent (g), and $V$ is the volume of the fluoride solution (L).

The adsorption capacity $Q$ is the amount of adsorbate taken up by the adsorbent per unit mass of the adsorbent as defined below (Equation (2)):

$$
Q=\frac{\left(C_{0}-C_{t}\right) \cdot V}{m}
$$

where $C_{0}$ and $C_{t}$ are the concentrations before and after a certain time $t$ of adsorption $(\mathrm{mg} / \mathrm{L})$, respectively.

The adsorption efficiency $E$ is calculated as the percent decrease in fluoride concentration from the initial value (Equation (3)):

$$
E=\frac{C_{0}-C_{t}}{C_{0}} \times 100 \%
$$

\subsection{Regeneration}

A total of $20 \mathrm{~mL}$ of $1: 1(v / v)$ mixed solution of $0.01 \mathrm{M}$ sodium nitrate and $0.1 \mathrm{M}$ sodium hydroxide was used for the regeneration of the $\mathrm{Zn}-\mathrm{Al} \mathrm{LDH}$ foams after fluoride adsorption. A $3 \mathrm{mg} / \mathrm{L}$ fluoride solution was used for the readsorption process. The fluoride desorption and readsorption processes were both carried out for $24 \mathrm{~h}$ at room temperature in a nitrogen environment. The adsorption-regeneration-readsorption process was performed to study the possibility of reusing the adsorbent. The regeneration efficiency was calculated by measuring the recovered adsorption efficiency for fluoride.

\section{Results}

\subsection{Zn-Al LDH Film Synthesis}

Table 1 summarizes the effects of the different methods of synthesis and types of foam on the growth of $\mathrm{Zn}-\mathrm{Al} \mathrm{LDH}$ with specific regard to the quantity of deposited $\mathrm{LDH}$ material. The absolute weight of LDH and the mass percentage relative to the mass of original aluminum foam ( $\mathrm{LDH} / \mathrm{Al}$ ) are reported in the first and second columns, respectively. As expected, the mass of deposited LDH generally increased with both the methods that involved a second growth, but without a clear indication on the best performer. In the case of Type I foam, the highest percentage (2.32\%) was obtained by the continuous two growths (CTG) method. However, for Type II foam, a slightly higher value $(2.51 \%)$ was obtained by separate two growths (STG). By using STG, the LDH percentage was approximately doubled in comparison with single growth (SG), both for Type I and Type II foams. This was partially confirmed in the case of CTG since a slightly different result was obtained for the two types of foams. However, over all types of foams under investigation, the $\mathrm{LDH} / \mathrm{Al}$ mass ratio seemed to reach its limit at around $2.5 \%$. These results can be referred to the limited surface area of the foams, as the salts added for the synthesis were always in excess. To obtain the highest percentage of adsorbent mass, the Type II foam with separate two growths (STG) can be the best option.

Table 1. LDH synthesis results.

\begin{tabular}{cccc}
\hline & Samples & LDH [g] & LDH/Al [\%] \\
\hline \multirow{3}{*}{ Type I } & I-SG & 0.0059 & 0.83 \\
& I-STG & 0.0114 & 1.97 \\
& I-CTG & 0.0166 & 2.32 \\
\hline \multirow{3}{*}{ Type II } & II-SG & 0.0070 & 1.25 \\
& II-STG & 0.0147 & 2.51 \\
& II-CTG & 0.0099 & 1.93 \\
\hline
\end{tabular}




\subsection{Characterization}

\subsubsection{XRD Characterization}

Figure 2 shows the XRD spectra of a I-SG LDH sample and the $\mathrm{Al}$ foam substrate before the synthesis. After synthesis, the diffraction pattern clearly shows the reflections of both $\mathrm{Al}$ from the substrate and the $\mathrm{Zn}-\mathrm{Al} \mathrm{LDH}$ film grown on the foam.

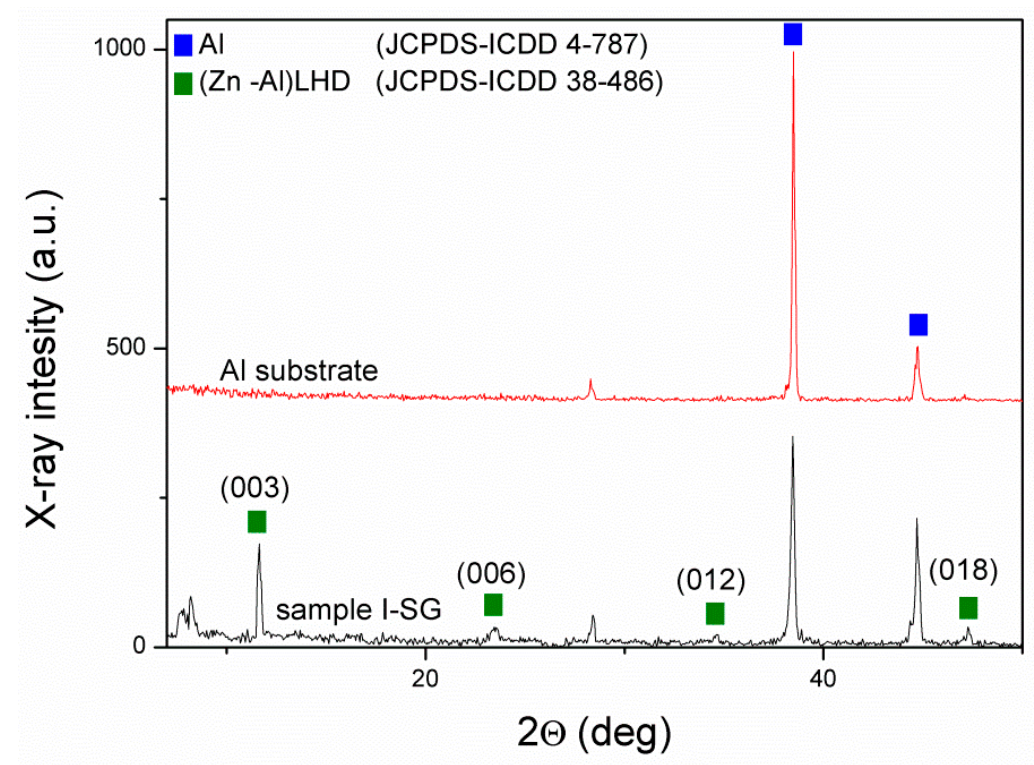

Figure 2. XRD spectrum of sample I-SG before fluoride adsorption. For comparison Al substrate spectrum before the synthesis is also reported.

XRD analysis confirms the hexagonal Zn-Al LDH crystal structure with rhombohedral $3 R$ symmetry, as generally reported in the literature $[18,53]$. Specifically, the formation of hydrotalcite-like $\mathrm{LDH}$ is shown by the peaks at $11.59^{\circ}, 23.44^{\circ}, 34.64^{\circ}$, and $47.27^{\circ}$ that are ascribed to (003), (006), (012) and (018) reflections (JCPDS-ICDD 38-486). The diffraction peaks at $2 \theta$ of $38.45^{\circ}$ and $44.72^{\circ}$ are assigned to (111) and (200) reflections of $\mathrm{Al}$ (JCPDSICDD 4-787), while the peak at $2 \theta=7.42^{\circ}$ is ascribed to $\beta$-alumina (JCPDS-ICDD 10-414). The positions of symmetric (00l) and asymmetric $(0 \mathrm{kl})$, (h0l) reflections of the hydrotalcitelike LDH phase allow the determination of the lattice parameter $c$ and $a$ by using the Bragg law and the equation for the distance between adjacent planes $(d)$ in a hexagonal lattice:

$$
\frac{1}{d^{2}}=\frac{4}{3}\left(\frac{h^{2}+h k+k^{2}}{a^{2}}\right)+\frac{l^{2}}{c^{2}}
$$

where $h, k$, and $l$ are the Miller indices.

In particular, the positions of the two symmetric reflections, (003) and (006), can be used to calculate the average value of the cell parameter $c=(1 / 2)\left(3 d_{003}+6 d_{006}\right)=22.75 \AA$. Then, the asymmetric (018) reflection was used to determine $a=3.01 \AA$. The results are in good agreement with those of the literature [45,53,54].

For comparison, the spectra of $\mathrm{Zn}-\mathrm{Al} \mathrm{LDH}$ synthesized with different methods were analyzed and, in order to investigate the crystalline texture, the relative intensities were compared with those of the same material with random grain orientation, taken from the JCPDS-ICDD database. The results show the presence of both the basal reflections, (003) and (006), giving evidence of parallel-oriented LDH nanoplatelets, and some asymmetric reflections from almost perpendicular-oriented nanoplatelets for all the samples (Figure S1). Only for the I-STG sample are textures with (018) and (012) components visible (Table S1), suggesting the presence of differently grown LDH nanoplatelets, in agreement with the differences observed in the SEM analysis (see Figure 3c below). 

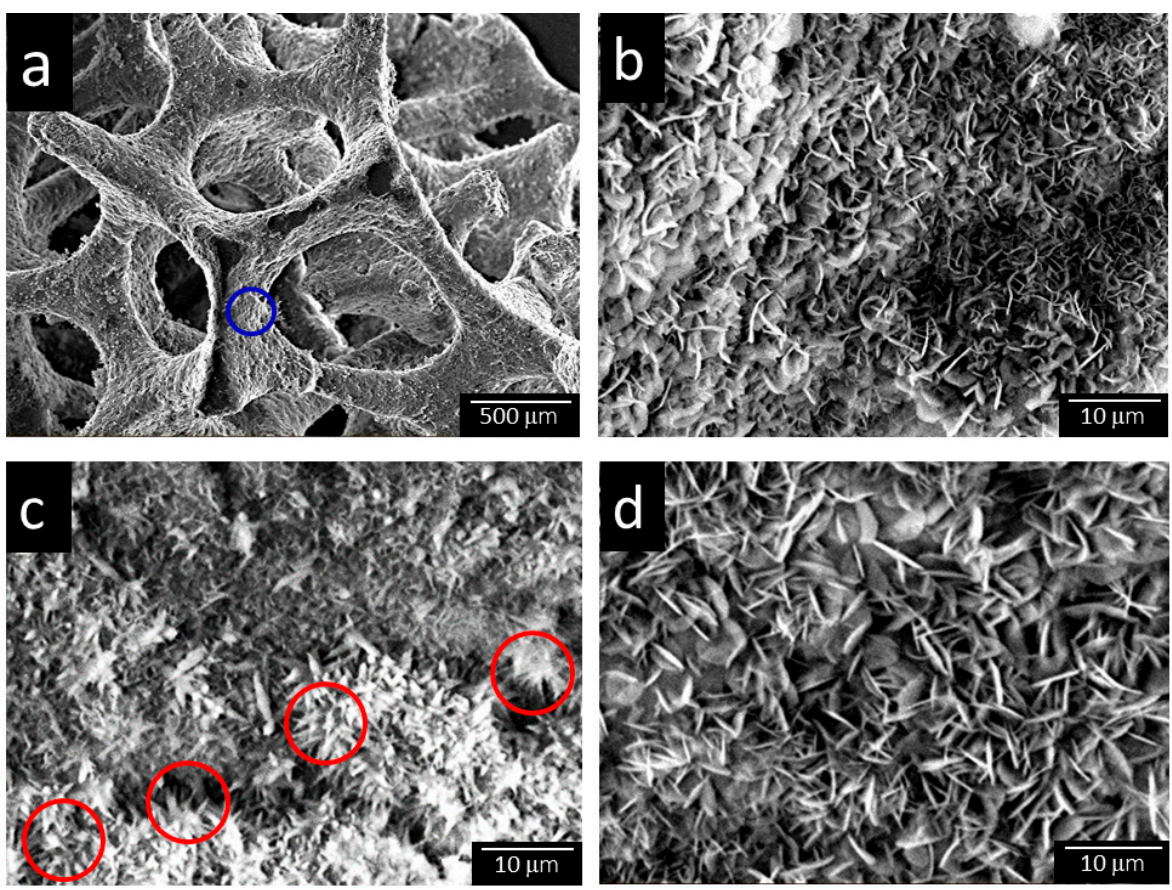

Figure 3. SEM images of: (a) Type I foam with single growth (I-SG); (b) higher-magnification image of the blue-circled area in Figure 3a of type I foam with single growth (I-SG); (c) Type I foam with separate two growths (I-STG), the red circles showing the presence of sea urchin nanostructures (see text); (d) Type I foam with continuous two growths (I-CTG).

\subsubsection{SEM Characterization}

The SEM micrographs of $\mathrm{Zn}-\mathrm{Al} \mathrm{LDH}$ grown onto aluminum foams are shown in Figure 3. It was confirmed that even SG synthesis by the urea method was sufficient to produce a dense layer of LDH nanostructures covering all the surface of the aluminum foam, independently of the foam type (Figure 3a). The LDH films were made of the typical nanoplatelets with an approximately circular shape and lateral dimensions in the range 3-5 $\mu \mathrm{m}$ (Figure 3b) generally observed in in situ growth [41,42]. In particular, Figure 3b shows the zoomed-in image of the circled area of Figure 3a. Through observations of several zones, Figure $3 \mathrm{~b}$ could be considered representative of the morphology of the LDH film over the entire surface, even though variations in the shape, size and density of the nanoplatelets were observed. The films deposited with the second growth by the coprecipitation method (STG) consisted of much smaller nanoplatelets (Figure 3c). Some needle-shaped sea urchin nanostructures [55] also formed on the top of the layer (red circles), and they can be attributed to zinc oxide $(\mathrm{ZnO})$ formed during the coprecipitation reaction [56,57], as confirmed by XPS characterization (see Section 3.2.3). Differently, a second growth by the CTG method (Figure 3d) produced more uniform, flatter and slightly bigger LDH nanosheets, probably resulting from the further growth of the original nanoplatelets formed with the first growth. From this point of view, the synthesis with continuous growth by the urea method (CTG) is the best choice to obtain more regular $\mathrm{Zn}-\mathrm{Al} \mathrm{LDH}$ films on the foams, also with a simplified synthesis procedure.

\subsubsection{XPS Characterization}

Figure 4 displays the XPS survey spectra of the II-STG sample as synthesized (Figure 4a) and after fluoride adsorption (Figure $4 \mathrm{~b}$ ). In both the spectra are marked the peaks of the main constituent elements, $\mathrm{Zn}, \mathrm{Al}, \mathrm{O}$ and $\mathrm{C}$. The appearance of the $\mathrm{F} 1 \mathrm{~s}$ peak at binding energy (BE) around $684 \mathrm{eV}$ evidenced in Figure $4 \mathrm{~b}$ after the adsorption of $10 \mathrm{mg} / \mathrm{L}$ fluoride solution indicates that fluoride was adsorbed by the LDH film. A high increase of $\mathrm{O} 1 \mathrm{~s}$ peak after fluoride adsorption indicates a strong oxidation of the film surface, leading to the decreased intensities of the $\mathrm{Zn}$ and $\mathrm{Al}$ signals. 

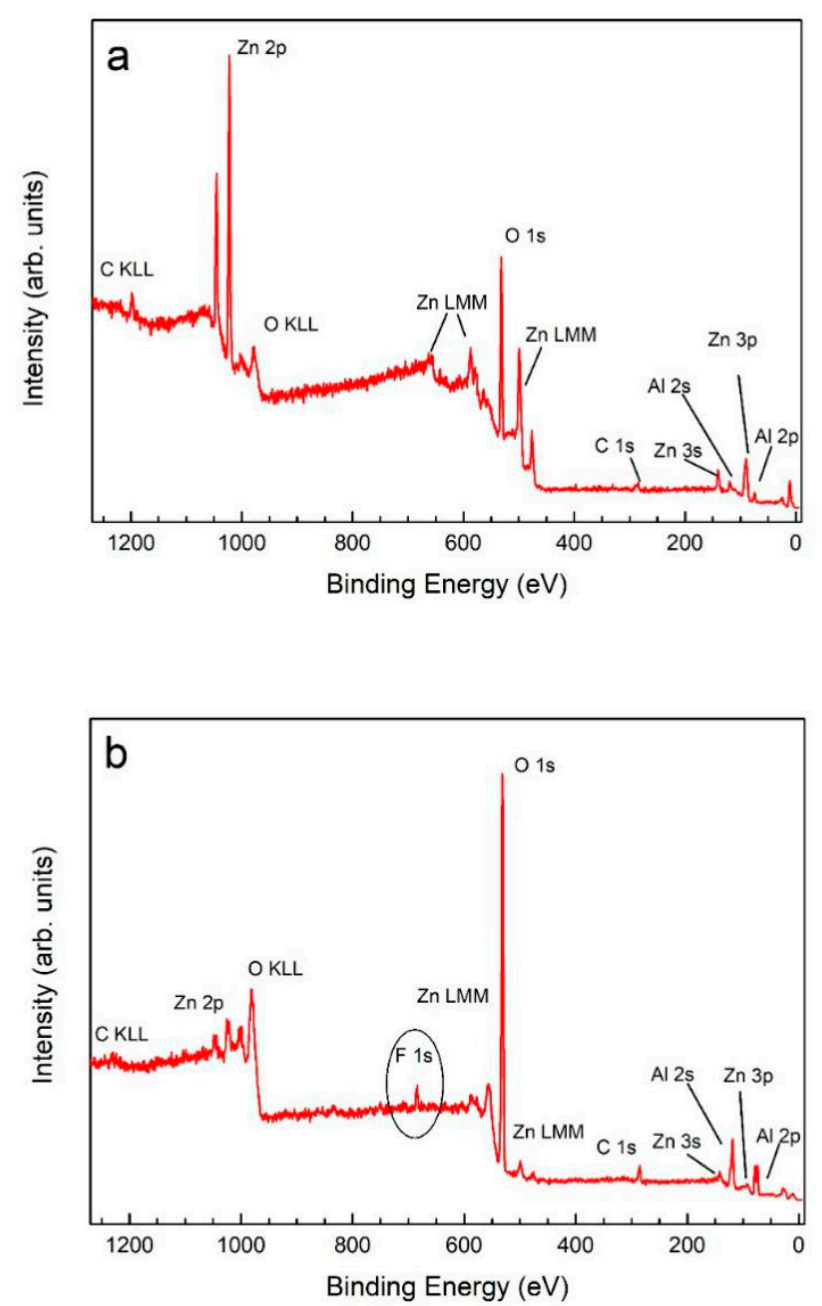

Figure 4. XPS survey spectra of the II-STG sample: before (a) and after (b) fluoride adsorption.

The high-resolution spectrum of the F 1s region (Figure 5) also confirms that fluoride is successfully bound to the sorbent material. Furthermore, in the high-resolution spectrum of the $\mathrm{Zn} 2 \mathrm{p}$ region, presented in Figure 6, in addition to the component $\mathrm{A}$ of $\mathrm{Zn} 2 \mathrm{p}_{3 / 2}$ peak at $\mathrm{BE}$ of about $1022 \mathrm{eV}$, corresponding to the $\mathrm{ZnO}$ signal, a new component $\mathrm{B}$ at $\mathrm{BE}=1024.7 \mathrm{eV}$ appeared after fluoride adsorption, confirming that fluorine was bonded with zinc to form $\mathrm{ZnF}_{2}$.

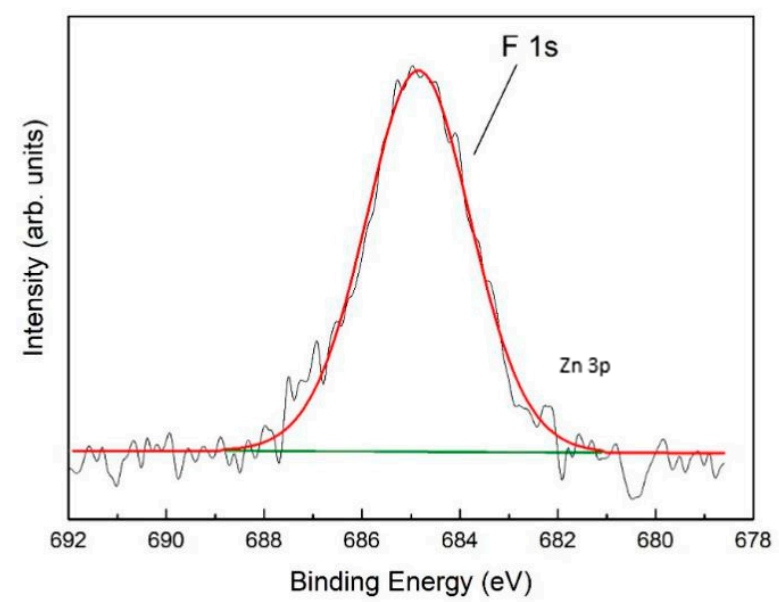

Figure 5. XPS spectrum of F 1s region of the sample II-STG after adsorption of $10 \mathrm{mg} / \mathrm{L}$ fluoride solution. 

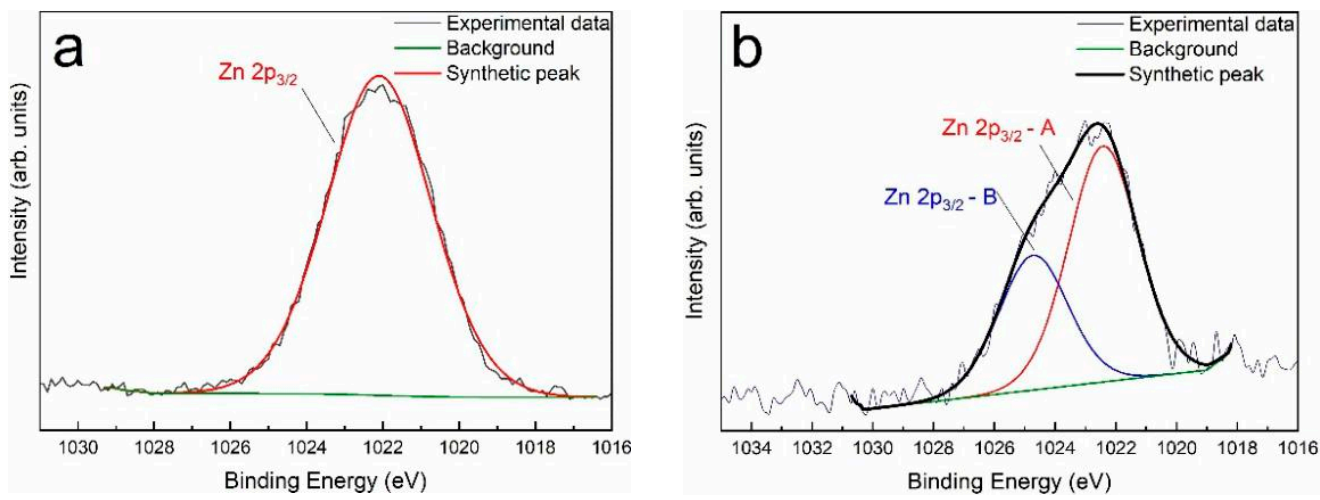

Figure 6. XPS spectra of Zn 2p region of the sample II-STG before (a) and after (b) adsorption of $10 \mathrm{mg} / \mathrm{L}$ fluoride solution.

The high-resolution spectra of the $\mathrm{O} 1 \mathrm{~s}$ region (Figure 7) were composed of two peaks that are assigned to metal oxides (denoted as $\mathrm{M}-\mathrm{O}, \mathrm{M}=\mathrm{Zn}$ or $\mathrm{Al}$ ) at $\mathrm{BE}=530.9 \mathrm{eV}(\mathrm{A})$ and to hydroxyl groups (denoted as $\mathrm{O}-\mathrm{H}$ ), nitrate group and carbonate groups (denoted as $\mathrm{C}=\mathrm{O}$ ) at $\mathrm{BE}=531.2 \mathrm{eV}(\mathrm{B})$. After fluoride adsorption, the atomic percentage of component B decreased from $33.9 \%$ to $26.4 \%$, whereas that of component A increased from $20.5 \%$ to $32.1 \%$, indicating that fluoride adsorption proceeds through ligand exchange with the hydroxyl groups or anion exchange with nitrate groups $[44,58,59]$.
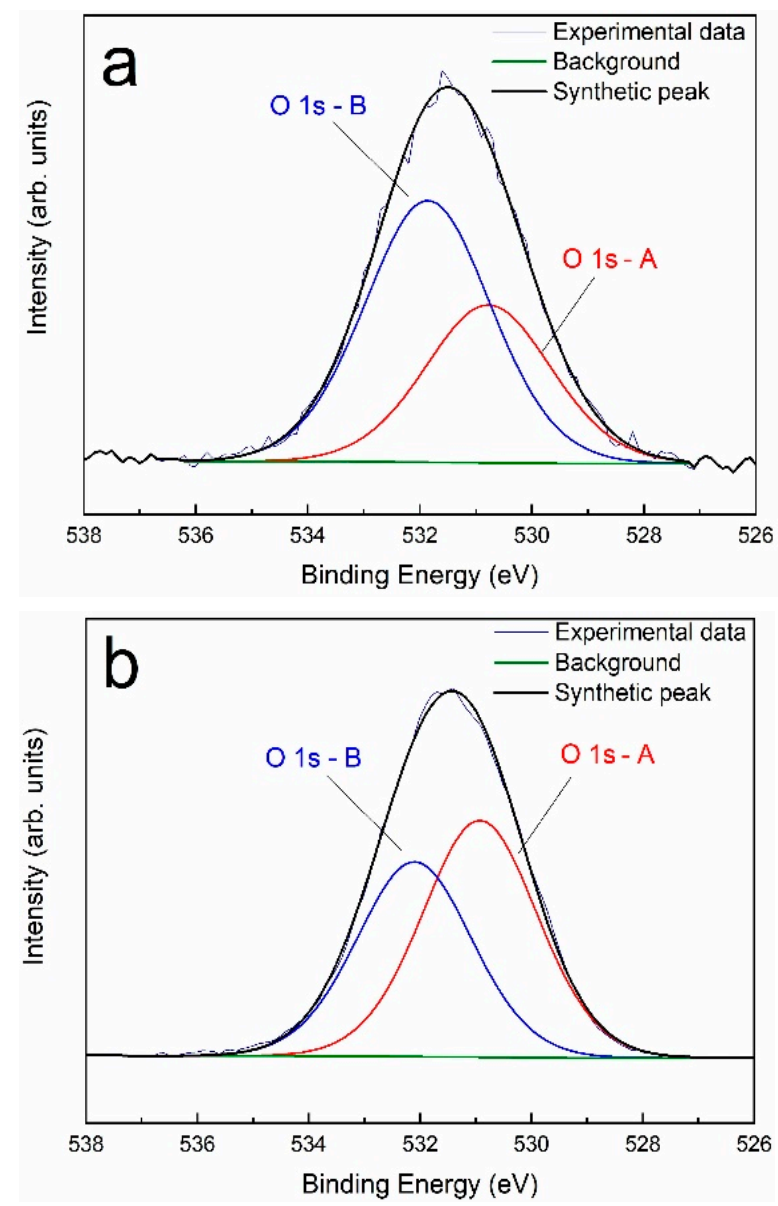

Figure 7. XPS spectra of $\mathrm{O}$ 1s region acquired for the sample II-STG before (a) and after (b) adsorption of $10 \mathrm{mg} / \mathrm{L}$ fluoride solution. The components of $\mathrm{O} 1 \mathrm{~s}$ spectra correspond to the peaks of metal oxides (A) and $\mathrm{O}-\mathrm{H}$ and $\mathrm{C}=\mathrm{O}$ bonds (B). 
When fluoride is removed from an aqueous solution by LDH, the adsorption probably occurs primarily in response to Coulomb attractions between the anionic adsorbent and the positively charged external and interlayer surfaces of LDH via the memory effect [60]. The mechanism of fluoride adsorption by LDH goes on as below (Equations (5) and (6)):

(i) Anion exchange between the interlayered nitrate and fluoride in solution with the formation of the outer-sphere complex:

$$
\mathrm{Zn}_{1-x}^{2+} A l_{x}^{3+}(\mathrm{OH})_{2}\left(\mathrm{NO}_{3}^{-}\right)_{x}+x F^{-} \rightarrow \mathrm{Zn}_{1-x}^{2+} A l_{x}^{3+}(\mathrm{OH})_{2}\left(F^{-}\right)_{x}+x \mathrm{NO}_{3}^{-}
$$

(ii) Ligand exchange between surface metal hydroxyl groups (M-OH) of $\mathrm{Zn}-\mathrm{Al} \mathrm{LDH}$ and fluoride in solution with the formation of the inner-sphere complex:

$$
>\mathrm{M}-\mathrm{OH}+\mathrm{F}^{-} \rightarrow \mathrm{M}-\mathrm{F}+\mathrm{OH}^{-}
$$

where $M$ is $\mathrm{Zn}$ or $\mathrm{Al}$.

\subsection{Fluoride Removal Experiment \\ 3.3.1. Effect of Contact Time}

To study the effect of the adsorption time, water samples were withdrawn from the defluorination bath at specific intervals between 0 and $24 \mathrm{~h}$. Figure 8 displays the fluoride removal process through the adsorption capacity (Figure 8a) and adsorption efficiency (Figure 8b) as a function of the contact time for an I-SG sample with two different initial fluoride concentrations. In both cases, the process seems to follow a typical exponential behavior toward a state of equilibrium with a very fast start which reaches half of the final value during the first hour. Adsorption slowed down considerably after $2 \mathrm{~h}$ and approached the saturation value after $4 \mathrm{~h}$ approximately. Generally, the decrease in adsorption rate is considered a consequence of a lower fluoride concentration and less active sites on the LDH adsorbent surface. The active sites were all available in the initial phase and became increasingly occupied with fluoride ions during the adsorption [61].

\subsubsection{Effect of Initial Concentration}

As shown in Figure 8, both the adsorption capacity and adsorption efficiency increased with the increasing initial fluoride concentration, from $3 \mathrm{mg} / \mathrm{L}$ to $10 \mathrm{mg} / \mathrm{L}$. This suggests that the driving force due to the concentration difference inside and outside the interlayers of $\mathrm{LDH}$ is the major contribution to the adsorption process in this low-concentration regime.

The mechanism of fluoride adsorption by LDH can be based on ion exchange or superficial adsorption in the interlamellar space as indicated in the XPS measurements. Specifically, the adsorption capacity increased by a factor of 5 approximately (from $2.93 \mathrm{mg} / \mathrm{g}$ to $15.06 \mathrm{mg} / \mathrm{g}$ ) when the concentration was increased from $3 \mathrm{mg} / \mathrm{L}$ to $10 \mathrm{mg} / \mathrm{L}$, with a slope greater than one, thus suggesting that the fraction of occupied adsorption sites per unit mass was quite low and the adsorption process was far from a saturated state. Therefore, the LDH adsorbent demonstrated to work well even when the initial fluoride concentration was higher than $10 \mathrm{mg} / \mathrm{L}$, in agreement with reference [62], where the adsorption capacity increased linearly with the fluoride concentration before reaching $20 \mathrm{mg} / \mathrm{L}$.

\subsubsection{Effect of $\mathrm{pH}$}

The fluoride adsorption in the range of $\mathrm{pH}$ from 5 to 10 is displayed in Figure 9. Generally, acidic $\mathrm{pH}$ values, i.e., lower than 5, were not taken into account in the literature due to the formation of the weakly ionized hydrofluoric acid (HF) and the possible dissolution of LDH. On the other hand, when $\mathrm{pH}$ is higher than 10 , aluminum dissolution from the layered structure could cause the reduction of the adsorption capacity [58]. In the present study, the original $\mathrm{pH}$ of $10 \mathrm{mg} / \mathrm{L}$ fluoride solution was 6; $\mathrm{pH}$ below 6 was obtained by adding a $0.01 \mathrm{M}$ solution of $\mathrm{HNO}_{3}$, while a $\mathrm{pH}$ from 7 to 10 was adjusted by adding $0.01 \mathrm{M}$ $\mathrm{NaOH}$ solution. The adsorption of fluoride increased with increasing $\mathrm{pH}$ below 6 , which can be due to both chemical and electrostatic interaction between fluoride ions and the 
oxide surface. When the $\mathrm{pH}$ increased over 6 , the decrease in fluoride adsorption with increasing $\mathrm{pH}$ (higher concentration of $\mathrm{OH}^{-}$) was attributed to the competition between $\mathrm{OH}^{-}$and $\mathrm{F}^{-}$for the exchangeable sites, and the inhibition of the ligand exchange process. The adsorption at $\mathrm{pH} 6$ occurred without any influence of competing ions $\left(\mathrm{NO}_{3}{ }^{-}\right.$ or $\left.\mathrm{OH}^{-}\right)$and reached the highest adsorption capacity $(8.45 \mathrm{mg} / \mathrm{g})$ and efficiency $(43.5 \%)$ of the $\mathrm{pH}$ range from 5 to 10 . This result is in good agreement with that reported in the literature $[59,62,63]$.
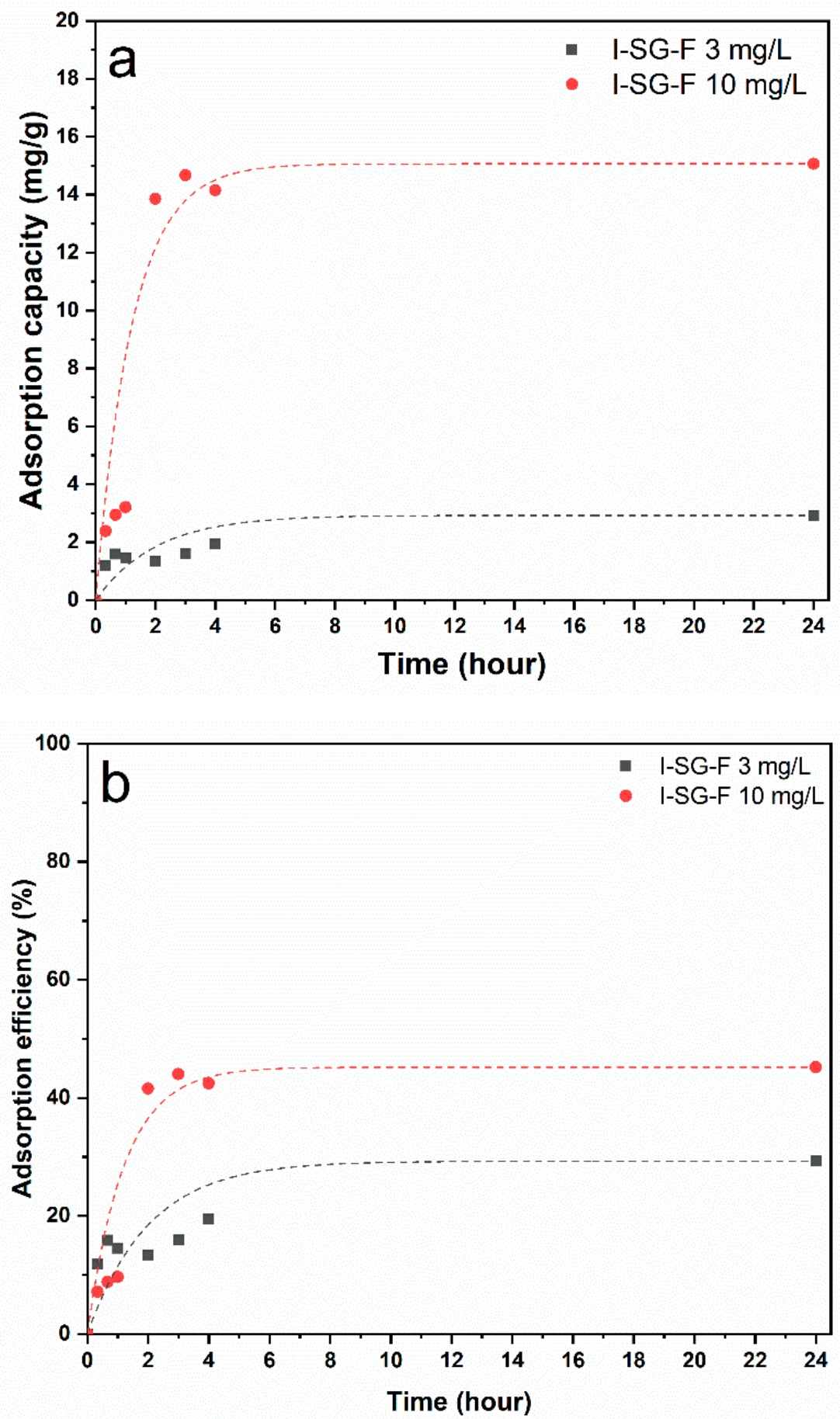

Figure 8. Adsorption capacity (a) and adsorption efficiency (b) as a function of the contact time of I-SG samples with initial fluoride concentration of $3 \mathrm{mg} / \mathrm{L}$ and $10 \mathrm{mg} / \mathrm{L}$, adsorbent dose $0.30 \mathrm{~g} / \mathrm{L}$. The dashed lines are guides for the eye and represent an exponential behavior. 

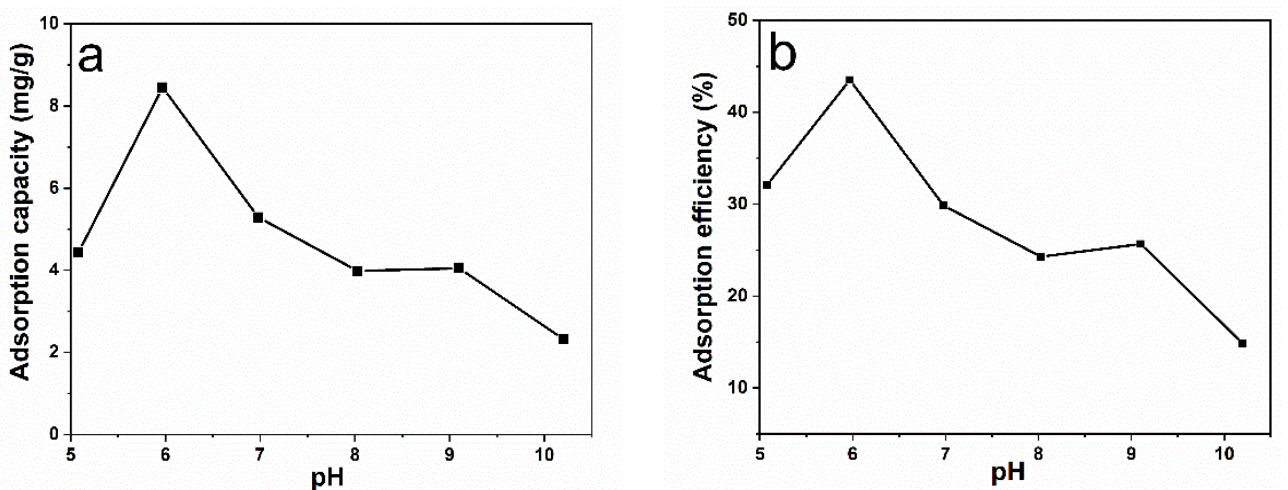

Figure 9. Fluoride adsorption capacity (a) and adsorption efficiency (b) of II-STG under different $\mathrm{pH}$, $20 \mathrm{~mL}$ of $10 \mathrm{mg} / \mathrm{L}$ fluoride solution, room temperature, $24 \mathrm{~h}$.

\subsubsection{Effect of the Adsorbent Dosage}

Figure 10 shows that the adsorption efficiency has a non-linear relationship with the adsorption dosage, similar to the trend generally found in the literature $[3,31,64]$. As the adsorbent dosage increases, the adsorption efficiency increases at a lower rate and seems to approach equilibrium when the adsorbent dosage is over $0.75 \mathrm{~g} / \mathrm{L}$. It can be seen that the fluoride removal increased from $29.3 \%$ to $67.2 \%$ when the adsorbent dose increased from $0.3 \mathrm{~g} / \mathrm{L}$ to $0.75 \mathrm{~g} / \mathrm{L}$. According to the surface site heterogeneous theory [65], the surface is composed of different types of adsorption sites. At low adsorbent dosage, all types of sites are exposed for adsorption, and the surface reaches saturation faster. However, at high concentrations of the adsorbent, lower energy sites are occupied at a higher fraction than higher energy sites. In the present study, the highest removal efficiency in all the samples was reached by II-STG, with $0.75 \mathrm{~g} / \mathrm{L}$ adsorbent dose.

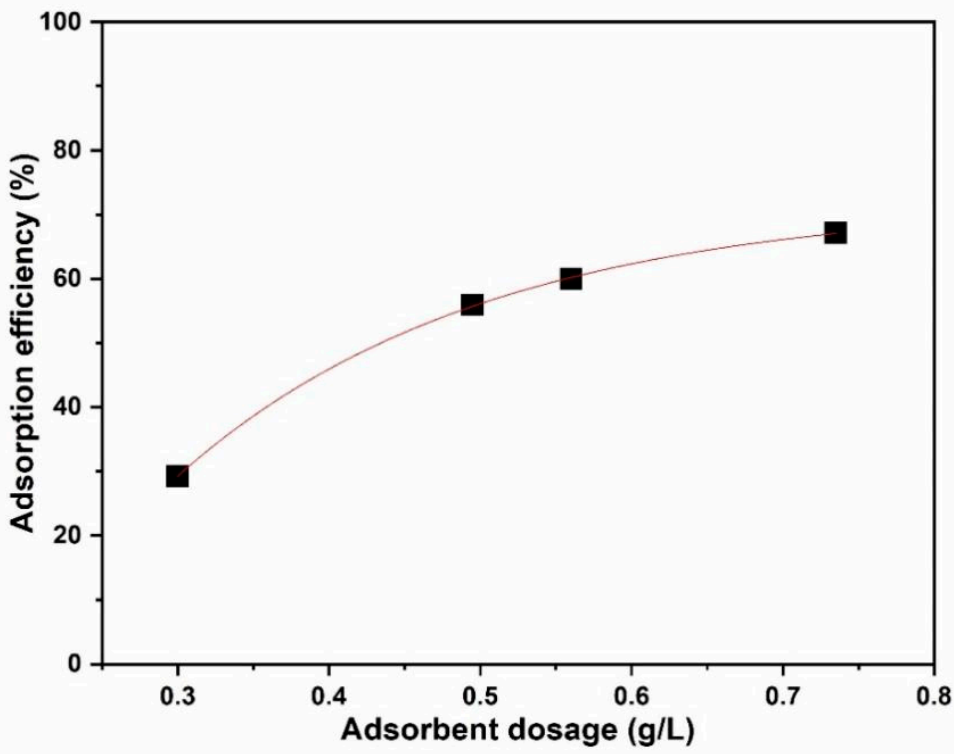

Figure 10. The adsorption efficiency as a function of the adsorbent dosage, experimental conditions: room temperature, $3 \mathrm{mg} / \mathrm{L}$ fluoride solution, $24 \mathrm{~h}$ of contact time. The continuous line is a guide for the eye.

\subsubsection{Effect of Foam Type and Synthesis Method}

To investigate the effect of the various growth types and parameters on the adsorption process, the defluorination experiment was performed with different samples at the same initial fluoride concentration of $3 \mathrm{mg} / \mathrm{L}$. Figure 11 shows the adsorption capacity (Figure 11a) and adsorption efficiency (Figure 11b) as a function of the contact time for 
samples grown with the different methods and foams: II-CTG, I-STG, II-STG and I-SG. It can be seen that the adsorption capacity reached a similar value around $3 \mathrm{mg} / \mathrm{g}$ after $24 \mathrm{~h}$ for all the samples (Figure 11a), which suggests that the amount of absorbed fluoride basically increases linearly with the adsorbent quantity, without a strong dependence on the method of synthesis and type of foam. With double growth methods (STG, CTG), the adsorption capacity was slightly higher than with single growth ones, possibly due to the larger exposed area produced by the hierarchical growth of the two subsequent layers. As a consequence of the similar adsorption capacity, the adsorption efficiency varied in accordance with the amount of synthesized LDH films (see Table 1) with sample II-STG showing the highest adsorption efficiency at approximately $67 \%$ after $24 \mathrm{~h}$. This resulted in a decrease in fluoride concentration from $3 \mathrm{mg} / \mathrm{L}$ to $1.1 \mathrm{mg} / \mathrm{L}$, approximately, which is below the $1.5 \mathrm{mg} / \mathrm{L}$ limit for drinking water set by WHO.
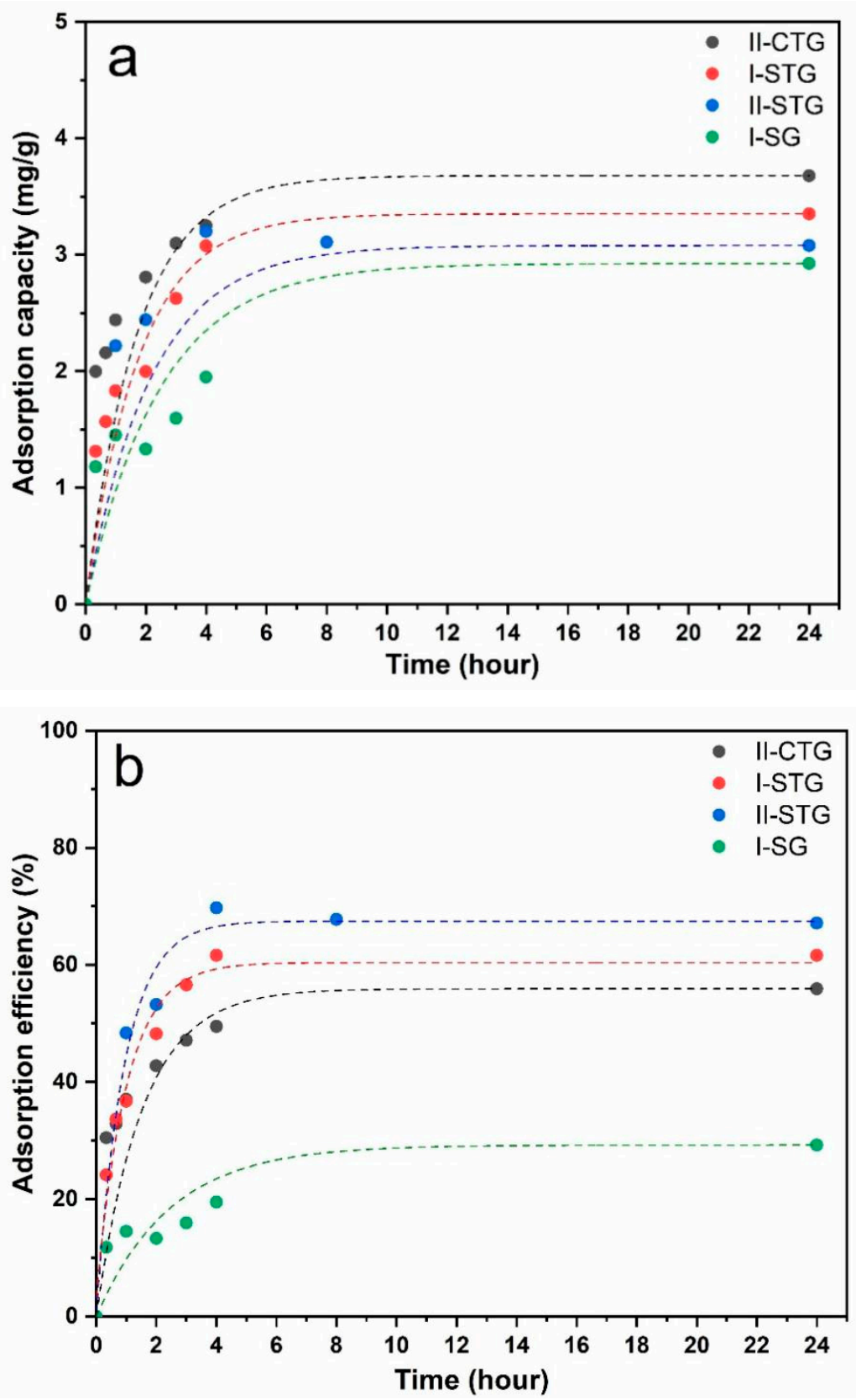

Figure 11. Adsorption capacity (a) and adsorption efficiency (b) of samples II-CTG, II-STG, II-SG, I-STG and I-SG, room temperature, $3 \mathrm{mg} / \mathrm{L}$ fluoride solution. The dashed lines are guides for the eye and represent an exponential behavior. 


\subsubsection{Adsorption Kinetics}

Experimental data were fitted with either a pseudo-first-order model or a pseudosecond-order model. When the pseudo-first-order model is best fitted with $R^{2}$ value close to 1 , it indicates that the reaction is more toward physisorption. In the case of a pseudosecond-order model, the reaction is more toward chemisorption. The equation of each model is shown below (Equations (7) and (8)):

$$
\begin{array}{r}
\text { Pseudo-first-order model } \ln \left(q_{e}-q_{t}\right)=\ln q_{e}-k_{1} t \\
\text { Pseudo- sec ond-order model } \quad \frac{t}{q_{t}}=\frac{t}{q_{e}}+\frac{1}{k_{2} q_{e}^{2}}
\end{array}
$$

where $q_{e}$ and $q_{t}$ are the adsorption capacity at equilibrium and at time $t$, and $k_{1}$ and $k_{2}$ are the rate constants of the first order and second order, respectively.

As shown in Figures 12 and 13, both the pseudo-first-order and the pseudo-secondorder models fitted the experimental data reasonably, suggesting that both chemisorption and physisorption occurred during the adsorption process. However, on closer examination, over the first two-hour adsorption, fitting with pseudo-second-order model is more accurate, with $\mathrm{R}^{2}=0.999$, higher than that obtained with pseudo-first-order model $\left(R^{2}=0.996\right)$. This indicates that chemisorption dominated in the initial stage of adsorption process. The kinetic coefficient $\mathrm{k}_{2}$ was calculated to be $0.60 \mathrm{~L} /(\mathrm{mg} \cdot \mathrm{h})$, and the equilibrium adsorption quantity $\mathrm{Q}$ is $3.73 \mathrm{mg} / \mathrm{g}$.

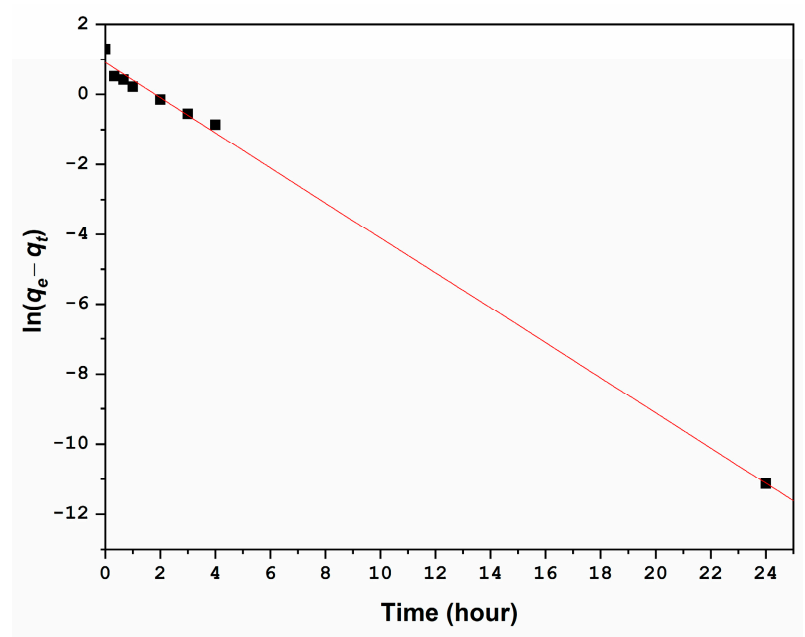

Figure 12. Fitting of fluoride adsorption data in II-CTG Zn-Al LDH with pseudo-first-order kinetic model. Experimental conditions: sorbent dosage $0.495 \mathrm{mg} / \mathrm{L}$, equilibrium $\mathrm{pH}=6.5 \pm 0.5$, initial fluoride concentration $3 \mathrm{mg} / \mathrm{L}$.

\subsubsection{Regeneration}

The regeneration procedure of used foams was performed on samples II-STG and II-CTG. A total of $20 \mathrm{~mL}$ of $1: 1(v / v)$ mixed solution of $0.01 \mathrm{M} \mathrm{NaNO}_{3}$ and $0.1 \mathrm{M} \mathrm{NaOH}$ solutions was used as the basic medium to stimulate the fluoride desorption process. As shown in Figure 14, the adsorption efficiency decreased from the as-synthesized values of $67.2 \%$ and $55.9 \%$ to $16.8 \%$ and $13.9 \%$ after regeneration for II-STG and II-CTG, respectively. The recovered adsorption efficiency was clearly unsatisfactory in comparison to the results in the literature $[44,46]$, with only $25 \%$ of the first adsorption result. This could be due to the fact that the regeneration solution produced a certain degree of damage to the LDH film. In fact, after recycling, significant weight losses of $4 \%$ and $10 \%$ were recorded in the two samples, respectively. In the present case, the adsorption capacity cannot be calculated, as the real amount of sorbent on the aluminum foam cannot be measured after the initial adsorption stage. 


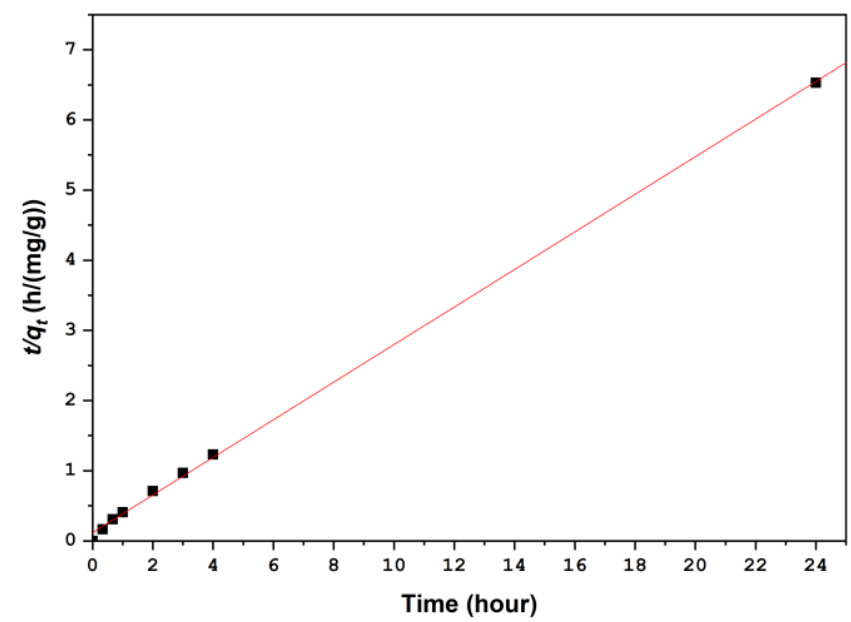

Figure 13. Fitting of fluoride adsorption data in II-CTG Zn-Al LDH with pseudo-second-order kinetic model. Experimental conditions: sorbent dosage $0.495 \mathrm{mg} / \mathrm{L}$, equilibrium $\mathrm{pH}=6.5 \pm 0.5$, initial fluoride concentration $3 \mathrm{mg} / \mathrm{L}$.

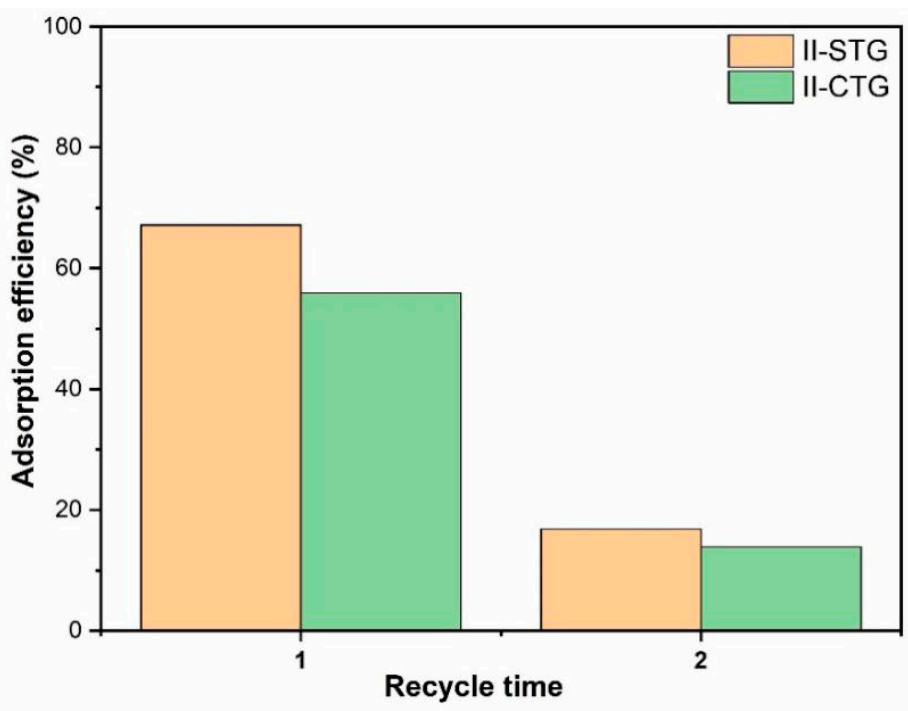

Figure 14. Adsorption efficiency of II-STG and II-CTG after adsorption-desorption-readsorption processes.

The desorption of fluorine, as well as the possible damage to the LDH film, are also confirmed by the XPS measurements. Indeed, the survey spectrum after regeneration, presented in Figure S2, reveals the absence of the F1s peak and a noticeable decrease in $\mathrm{Zn}$ signals. The II-STG sample after regeneration is composed mainly of $\mathrm{Al}(\mathrm{OH})_{3}$ and $\mathrm{Zn}(\mathrm{OH})_{2}$ with a small amount of $\mathrm{ZnO}$, as shown in the deconvolution of the $\mathrm{Zn} 2 \mathrm{p}$ and $\mathrm{O}$ 1s spectra reported in Figure S3. Furthermore, the total atomic ratio of Al:Zn, calculated from the XPS quantification before and after LDH regeneration, is increased from about 0.7 to 4 . This increase proves the partial damage of LDH film and reduction in the adsorption efficiency.

\section{Conclusions}

In this study, we presented a new method for fluoride removal from water based on nanostructured $\mathrm{Zn}-\mathrm{Al} \mathrm{LDH}$ films synthesized in situ on $\mathrm{Al}$ foams that acted as both the reactant for the growth and substrate for a simpler handling of the removal process. Three different methods of LDH synthesis were investigated: (1) single growth (SG); (2) separate two growths (STG); and (3) continuous two growths (CTG). XRD spectra and SEM images confirmed the successful growth of LDH on the surface of the Al foams. Both STG and 
CTG methods demonstrated to be effective in increasing the amount of LDH film through the second growth, as the mass of adsorbent almost doubled when compared with SG. Fitting with kinetic models showed that both physisorption and chemisorption occurred during the adsorption process, with the latter dominating the first stage of fluoride removal. XPS analysis revealed that the fluoride removal mainly occurred by the anion exchange and ligand exchange processes. The highest adsorption efficiency, with a value of $69.8 \%$, was reached after $4 \mathrm{~h}$, starting from the $3 \mathrm{mg} / \mathrm{L}$ initial fluoride concentration by using II-STG. This effectively reduced the fluoride concentration to $1.1 \mathrm{mg} / \mathrm{L}$, which is below the threshold value set by WHO for drinking water. The adsorption capacity increased when the initial fluoride concentration was increased from $3 \mathrm{mg} / \mathrm{L}$ to $10 \mathrm{mg} / \mathrm{L}$, as expected within a concentration-driven process, and the adsorption sites were proved not to reach a saturated state. The optimum condition for the adsorption was found to be at $\mathrm{pH} 6$, while, as expected, the foam type did not influence the adsorption capacity significantly. The results on recycling were quite disappointing, probably due to significant damage and weight loss occurring during the regeneration of the foams. To this end, further studies are in progress to improve this process by using different solutions and chemical reactions for desorption. However, the present study demonstrates the proof of concept that the use of an $\mathrm{Al}$ substrate can be a strategy to simplify and improve the adsorption processes for wastewater remediation. It is expected that $\mathrm{Zn}-\mathrm{Al} \mathrm{LDH}$ grown on aluminum foams can be potentially used as low-cost, efficient, and recycling adsorbent for the removal of fluoride and other contaminants from polluted water.

Supplementary Materials: The following are available online at https:/ / www.mdpi.com/article/10 .3390/pr9122109/s1, Figure S1: XRD spectra of I-SG, I-CTG and I-STG samples, Table S1: Comparison of the relative experimental XRD diffraction intensities with those of Al-Zn LDH powder with random oriented grains, Figure S2: XPS survey spectrum of the II-STG sample after regeneration, Figure S3: XPS spectra of Zn 2p (a) and O 1s (b) regions of the sample II-STG after regeneration.

Author Contributions: Conceptualization, Y.L. and R.N.; Investigation, Y.L., A.V., E.B. and S.K.; Supervision, R.P. and R.N. All authors have read and agreed to the published version of the manuscript.

Funding: This research received no external funding.

Acknowledgments: One of the authors (Y.L.) is grateful for the Erasmus Mundus Chemical Nanoengineering master program and the scholarship support. Our special thanks to Roberto Volterri for taking the SEM images.

Conflicts of Interest: The authors declare no conflict of interest.

\section{References}

1. Gai, W.Z.; Deng, Z.Y. A comprehensive review of adsorbents for fluoride removal from water: Performance, water quality assessment and mechanism. Environ. Sci. Water Res. Technol. 2021, 7, 1362-1386. [CrossRef]

2. Guiza, S.; Brouers, F.; Bagane, M. Fluoride removal from aqueous solution by montmorillonite clay: Kinetics and equilibrium modeling using new generalized fractal equation. Environ. Technol. Innov. 2021, 21, 101187. [CrossRef]

3. Tripathy, S.S.; Bersillon, J.L.; Gopal, K. Removal of fluoride from drinking water by adsorption onto alum-impregnated activated alumina. Sep. Purif. Technol. 2006, 50, 310-317. [CrossRef]

4. Habuda-Stanić, M.; Ravančić, M.; Flanagan, A. A Review on Adsorption of Fluoride from Aqueous Solution. Materials 2014, 7, 6317-6366. [CrossRef] [PubMed]

5. Yadav, K.K.; Gupta, N.; Kumar, V.; Khan, S.A.; Kumar, A. A review of emerging adsorbents and current demand for defluoridation of water: Bright future in water sustainability. Environ. Int. 2018, 111, 80-108. [CrossRef] [PubMed]

6. Wan, K.; Huang, L.; Yan, J.; Ma, B.; Huang, X.; Luo, Z.; Zhang, H.; Xiao, T. Removal of fluoride from industrial wastewater by using different adsorbents: A review. Sci. Total Environ. 2021, 773, 145535. [CrossRef]

7. Drouiche, N.; Djouadi-Belkada, F.; Ouslimane, T.; Kefaifi, A.; Fathi, J.; Ahmetovic, E. Photovoltaic solar cells industry wastewater treatment. Desalin. Water Treat. 2013, 51, 5965-5973. [CrossRef]

8. Teixeira, M.A.; Mageste, A.B.; Dias, A.; Virtuoso, L.S.; Siqueira, K.P.F. Layered double hydroxides for remediation of industrial wastewater containing manganese and fluoride. J. Clean. Prod. 2018, 171, 275-284. [CrossRef]

9. Rasool, A.; Farooqi, A.; Xiao, T.; Ali, W.; Noor, S.; Abiola, O.; Ali, S.; Nasim, W. A review of global outlook on fluoride contamination in groundwater with prominence on the Pakistan current situation. Environ. Geochem. Health 2017, 40, 1265-1281. [CrossRef] 
10. Maheshwari, R.C.M. Fluoride in drinking water and its removal. J. Hazard. Mater. 2006, 137, 456-463. [CrossRef]

11. Waghmare, S.S.; Arfin, T. Fluoride removal from water by various techniques. Int. J. Innov. Sci. Eng. Technol. 2015, 2, 560-571.

12. Grzegorzek, M.; Majewska-Nowak, K.; Ahmed, A.E. Removal of fluoride from multicomponent water solutions with the use of monovalent selective ion-exchange membranes. Sci. Total Environ. 2020, 722, 137681. [CrossRef]

13. Wei, L.; Li, Z.; Ye, G.; Rietveld, L.C.; van Halem, D. Comparative study of low-cost fluoride removal by layered double hydroxides, geopolymers, softening pellets and struvite. Environ. Technol. 2021. just-accepted: 1-20. [CrossRef]

14. Pizzoferrato, R.; Richetta, M. Layered double hydroxides (LDHs). Crystals 2020, 10, 1121. [CrossRef]

15. Daniel, S.; Thomas, S. Layered double hydroxides: Fundamentals to applications. In Layered Double Hydroxide Polymer NanoComposites; Woodhead Publishing: Sawston, UK, 2020; pp. 1-76. ISBN 9780081019030.

16. Johnston, A.L.; Lester, E.; Williams, O.; Gomes, R.L. Understanding Layered Double Hydroxide properties as sorbent materials for removing organic pollutants from environmental waters. J. Environ. Chem. Eng. 2021, 9, 105197. [CrossRef]

17. Miyata, S. Anion-exchange properties of hydrotalcite-like compounds. Clays Clay Miner. 1983, 31, 305-311. [CrossRef]

18. Bernardo, M.P.; Ribeiro, C. [Mg-Al]-LDH and [Zn-Al]-LDH as matrices for removal of high loadings of phosphate. Mater. Res. 2018, 21, 1-9. [CrossRef]

19. Roy, S.; Dass, G. Fluoride Contamination in Drinking Water-A Review. Resour. Environ. 2013, 3, 53-58. [CrossRef]

20. Li, T.; Miras, H.N.; Song, Y.F. Polyoxometalate (POM)-Layered Double Hydroxides (LDH) composite materials: Design and catalytic applications. Catalysts 2017, 7, 260. [CrossRef]

21. Yang, Z.Z.; Zhang, C.; Zeng, G.M.; Tan, X.F.; Wang, H.; Huang, D.L.; Yang, K.H.; Wei, J.J.; Ma, C.; Nie, K. Design and engineering of layered double hydroxide based catalysts for water depollution by advanced oxidation processes: A review. J. Mater. Chem. A 2020, 8, 4141-4173. [CrossRef]

22. Pizzoferrato, R.; Ciotta, E.; Ferrari, I.V.; Narducci, R.; Pasquini, L.; Varone, A.; Richetta, M.; Antonaroli, S.; Braglia, M.; Knauth, P.; et al. Layered Double Hydroxides Containing an Ionic Liquid: Ionic Conductivity and Use in Composite Anion Exchange Membranes. ChemElectroChem 2018, 5, 2781-2788. [CrossRef]

23. Yang, J.; Jing, R.; Wang, P.; Liang, D.R.; Huang, H.; Xia, C.; Zhang, Q.; Liu, A.; Meng, Z.; Liu, Y. Black phosphorus nanosheets and $\mathrm{ZnAl}-\mathrm{LDH}$ nanocomposite as environmental-friendly photocatalysts for the degradation of Methylene blue under visible light irradiation. Appl. Clay Sci. 2021, 200, 105902. [CrossRef]

24. Di Vona, M.L.; Casciola, M.; Donnadio, A.; Nocchetti, M.; Pasquini, L.; Narducci, R.; Knauth, P. Anionic conducting composite membranes based on aromatic polymer and layered double hydroxides. Int. J. Hydrogen Energy 2017, 42, 3197-3205. [CrossRef]

25. Kuthati, Y.; Kankala, R.K.; Lee, C.H. Layered double hydroxide nanoparticles for biomedical applications: Current status and recent prospects. Appl. Clay Sci. 2015, 112-113, 100-116. [CrossRef]

26. Tan, J.K.E.; Balan, P.; Birbilis, N. Advances in LDH coatings on Mg alloys for biomedical applications: A corrosion perspective. Appl. Clay Sci. 2021, 202, 105948. [CrossRef]

27. Arrabito, G.; Pezzilli, R.; Prestopino, G.; Medaglia, P.G. Layered double hydroxides in bioinspired nanotechnology. Crystals 2020, 10, 602. [CrossRef]

28. Chaillot, D.; Bennici, S.; Brendlé, J. Layered double hydroxides and LDH-derived materials in chosen environmental applications: A review. Environ. Sci. Pollut. Res. 2021, 28, 24375-24405. [CrossRef] [PubMed]

29. He, S.; Zhao, Y.; Wei, M.; Duan, X. Preparation of oriented layered double hydroxide film using electrophoretic deposition and its application in water treatment. Ind. Eng. Chem. Res. 2011, 50, 2800-2806. [CrossRef]

30. Zubair, M.; Daud, M.; McKay, G.; Shehzad, F.; Al-Harthi, M.A. Recent progress in layered double hydroxides (LDH)-containing hybrids as adsorbents for water remediation. Appl. Clay Sci. 2017, 143, 279-292. [CrossRef]

31. Chetia, M.; Goswamee, R.L.; Banerjee, S.; Chatterjee, S.; Singh, L.; Srivastava, R.B.; Sarma, H.P. Arsenic removal from water using calcined Mg-Al layered double hydroxide. Clean Technol. Environ. Policy 2012, 14, 21-27. [CrossRef]

32. Wang, S.; Gao, B.; Li, Y.; Zimmerman, A.R.; Cao, X. Sorption of arsenic onto Ni/Fe layered double hydroxide (LDH)-biochar composites. RSC Adv. 2016, 6, 17792-17799. [CrossRef]

33. Zhao, D.; Sheng, G.; Hu, J.; Chen, C.; Wang, X. The adsorption of Pb(II) on Mg2Al layered double hydroxide. Chem. Eng. J. 2011, 171, 167-174. [CrossRef]

34. Wang, L.; Wang, M.; Li, Z.; Gong, Y. Enhanced removal of trace mercury from surface water using a novel Mg2Al layered double hydroxide supported iron sulfide composite. Chem. Eng. J. 2020, 393, 124635. [CrossRef]

35. You, Y.; Vance, G.F.; Zhao, H. Selenium adsorption on Mg-Al and Zn-Al layered double hydroxides. Appl. Clay Sci. 2001, 20, 13-25. [CrossRef]

36. Kaciulis, S.; Bolli, E.; Varone, A.; Richetta, M.; Narducci, R.; Di Vona, M.L.; Ciotta, E.; Pizzoferrato, R. Adsorption of heavy metals by layered double hydroxides grown in situ on Al foam. Surf. Interface Anal. 2020, 52, 996-999. [CrossRef]

37. Li, Y.; Bi, H.Y.; Jin, Y.S. Facile preparation of rhamnolipid-layered double hydroxide nanocomposite for simultaneous adsorption of p-cresol and copper ions from water. Chem. Eng. J. 2017, 308, 78-88. [CrossRef]

38. Gao, H.; Cao, R.; Xu, X.; Xue, J.; Zhang, S.; Hayat, T.; Alharbi, N.S.; Li, J. Surface Area- and Structure-Dependent Effects of LDH for Highly Efficient Dye Removal. ACS Sustain. Chem. Eng. 2019, 7, 905-915. [CrossRef]

39. Barghouthi, Z.; Amereih, S. Spectrophotometric determination of fluoride in drinking water using aluminium complexes of triphenylmethane dyes. Water SA 2012, 38, 543-548. [CrossRef] 
40. Guo, X.; Yin, P.; Yang, H. Superb adsorption of organic dyes from aqueous solution on hierarchically porous composites constructed by $\mathrm{ZnAl}-\mathrm{LDH} / \mathrm{Al}(\mathrm{OH}) 3$ nanosheets. Microporous Mesoporous Mater. 2018, 259, 123-133. [CrossRef]

41. Shan, R.R.; Yan, L.G.; Yang, Y.M.; Yang, K.; Yu, S.J.; Yu, H.Q.; Zhu, B.C.; Du, B. Highly efficient removal of three red dyes by adsorption onto Mg-Al-layered double hydroxide. J. Ind. Eng. Chem. 2015, 21, 561-568. [CrossRef]

42. Halajnia, A.; Oustan, S.; Najafi, N.; Khataee, A.R.; Lakzian, A. Adsorption-desorption characteristics of nitrate, phosphate and sulfate on Mg-Al layered double hydroxide. Appl. Clay Sci. 2013, 80-81, 305-312. [CrossRef]

43. Lundehøj, L.; Cellier, J.; Forano, C.; Nielsen, U.G. Atomic Level Understanding of Orthophosphate Adsorption by Magnesium Aluminum-Layered Double Hydroxides-A Multitechnique Study. J. Phys. Chem. C 2019, 123, 24039-24050. [CrossRef]

44. Li, F.; Jin, J.; Shen, Z.; Ji, H.; Yang, M.; Yin, Y. Removal and recovery of phosphate and fluoride from water with reusable mesoporous Fe3O4@mSiO2@mLDH composites as sorbents. J. Hazard. Mater. 2020, 388, 121734. [CrossRef]

45. Pizzoferrato, R.; Ciotta, E.; Ferrari, I.V.; Braglia, M.; Medaglia, P.G.; Mattoccia, A.; Di Giamberardino, L.; Richetta, M.; Knauth, P.; Di Vona, M.L. Ionic conductivity of ZnAl layered double hydroxide films grown on aluminum substrate. Solid State Ionics 2018, 314, 30-35. [CrossRef]

46. He, S.; Zhao, Y.; Wei, M.; Evans, D.G.; Duan, X. Fabrication of hierarchical layered double hydroxide framework on aluminum foam as a structured adsorbent for water treatment. Ind. Eng. Chem. Res. 2012, 51, 285-291. [CrossRef]

47. Scarpellini, D.; Falconi, C.; Gaudio, P.; Mattoccia, A.; Medaglia, P.G.; Orsini, A.; Pizzoferrato, R.; Richetta, M. Morphology of $\mathrm{Zn} / \mathrm{Al}$ layered double hydroxide nanosheets grown onto aluminum thin films. Microelectron. Eng. 2014, 126, 129-133. [CrossRef]

48. Sasai, R.; Sato, H.; Sugata, M.; Fujimura, T.; Ishihara, S.; Deguchi, K.; Ohki, S.; Tansho, M.; Shimizu, T.; Oita, N.; et al. Why Do Carbonate Anions Have Extremely High Stability in the Interlayer Space of Layered Double Hydroxides? Case Study of Layered Double Hydroxide Consisting of $\mathrm{Mg}$ and $\mathrm{Al}(\mathrm{Mg} / \mathrm{Al}=2)$. Inorg. Chem. 2019, 58, 10928-10935. [CrossRef] [PubMed]

49. Iyi, N.; Okamoto, K.; Kaneko, Y.; Matsumoto, T. Effects of anion species on deintercalation of carbonate ions from hydrotalcite-like compounds. Chem. Lett. 2005, 34, 932-933. [CrossRef]

50. Dhillona, A.; Nair, M.; Kumar, D. Analytical methods for determination and sensing of fluoride in biotic and abiotic sources: A review. RSC 2016, 8, 5338-5352. [CrossRef]

51. Marques, T.L.; Coelho, N.M.M. Proposed flow system for spectrophotometric determination of fluoride in natural waters. Talanta 2013, 105, 69-74. [CrossRef]

52. Haj-Hussein, A.T.; Al-Momani, I.F. Indirect spectrophotometric determination of fluoride in water with zirconium-spadns by flow injection analysis. Anal. Lett. 1989, 22, 1581-1599. [CrossRef]

53. Liu, J.; Huang, X.; Li, Y.; Sulieman, K.M.; He, X.; Sun, F. Facile and large-scale production of ZnO/Zn-Al layered double hydroxide hierarchical heterostructures. J. Phys. Chem. B 2006, 110, 21865-21872. [CrossRef] [PubMed]

54. Babakhani, S.; Talib, Z.A.; Hussein, M.Z.; Ahmed, A.A.A. Optical and thermal properties of Zn/Al-layered double hydroxide nanocomposite intercalated with sodium dodecyl sulfate. J. Spectrosc. 2014, 2014, 467064. [CrossRef]

55. Kiriarachchi, H.D.; Abouzeid, K.M.; Bo, L.; El-Shall, M.S. Growth mechanism of sea urchin zno nanostructures in aqueous solutions and their photocatalytic activity for the degradation of organic dyes. ACS Omega 2019, 4, 14013-14020. [CrossRef]

56. Sugapriya, S.; Lakshmi, S.; Chandarshekar, B.; Ranjithkumar, R. ZnO Needle-like structures: Synthesis and characterization. Kongunadu Res. J. 2015, 2, 13-15. [CrossRef]

57. Malevu, T.D.; Ocaya, R.O.; Malevu, T.D.; Ocaya, R.O. Effect of Annealing Temperature on Structural, Morphology and Optical Properties of ZnO Nano-Needles Prepared by Zinc-Air Cell System Method. Artic. Int. J. Electrochem. Sci. 2015, 10, $1752-1761$.

58. Cai, J.; Zhao, X.; Zhang, Y.; Zhang, Q.; Pan, B. Enhanced fluoride removal by La-doped Li/ Al layered double hydroxides. J. Colloid Interface Sci. 2018, 509, 353-359. [CrossRef] [PubMed]

59. Yang, Y.; Du, X.; Abudula, A.; Zhang, Z.; Ma, X.; Tang, K.; Hao, X.; Guan, G. Highly efficient defluoridation using a porous MWCNT@NiMn-LDH composites based on ion transport of EDL coupled with ligand exchange mechanism. Sep. Purif. Technol. 2019, 223, 154-161. [CrossRef]

60. Kameda, T.; Oba, J.; Yoshioka, T. Recyclable Mg-Al layered double hydroxides for fluoride removal: Kinetic and equilibrium studies. J. Hazard. Mater. 2015, 300, 475-482. [CrossRef] [PubMed]

61. Bazrafshan, E.; Balarak, D.; Panahi, A.H.; Kamani, H.; Mahvi, A.H. Fluoride removal from aqueous solutions by cupricoxide nanoparticles. Fluoride 2016, 49, 233.

62. Das, D.P.; Das, J.; Parida, K. Physicochemical characterization and adsorption behavior of calcined Zn/Al hydrotalcite-like compound (HTlc) towards removal of fluoride from aqueous solution. J. Colloid Interface Sci. 2003, 261, 213-220. [CrossRef]

63. Mandal, S.; Mayadevi, S. Adsorption of fluoride ions by Zn-Al layered double hydroxides. Appl. Clay Sci. 2008, 40, 54-62. [CrossRef]

64. Zhang, T.; Li, Q.; Xiao, H.; Lu, H.; Zhou, Y. Synthesis of Li-Al layered double hydroxides (LDHs) for efficient fluoride removal. Ind. Eng. Chem. Res. 2012, 51, 11490-11498. [CrossRef]

65. Suchorski, Y.; Rupprechter, G. Heterogeneous Surfaces as Structure and Particle Size Libraries of Model Catalysts. Catal. Lett. 2018, 148, 2947-2956. [CrossRef] [PubMed] 